\title{
Ear drops, Powder for Suspension Dosage Form
}

National Cancer Institute

\section{Source}

National Cancer Institute. Ear drops, Powder for Suspension Dosage Form. NCI

Thesaurus. Code C149451.

Powder and solvent intended for the preparation of ear drops, suspension, by dispersing the powder in the solvent. 